\title{
PENGARUH KUALITAS, LOKASI DAN BIAYA TERHADAP KEPUTUSAN KULIAH DI IAIN SURAKARTA
}

\author{
Hapsari Nawaningsih, Eny Kustiyah, Ida Aryati \\ Prodi Manajemen Fakultas Ekonomi Universitas Islam Batik Surakarta \\ hapsarinawaningsih@gmail.com
}

\begin{abstract}
This study aims to find out and explain the influence both simultaneously and partially on the quality, location and cost of the lecture decisions at the Surakarta IAIN. This study took the Surakarta IAIN student population of 2018 semester 2 and a sample of 100 people taken $r$ andomly from all faculties. Data analysis using multiple linear regression analysis. The results of this study indicate that quality, location and costs have a simultaneous and significant effect on the lecture decisions at the Surakarta IAIN as evidenced by the Sig 0,000 and F count values of 28,984. In the t test the quality, location and cost have a positive and significant effect on college decisions at IAIN Surakarta with the quality values of Sig 0,000 and t count of 4,627, location values Sig 0.001 and tcount 3.541 and the cost value Sig 0.009 and tcount 2.667. Based on the test the coefficient of determination contributed $45.9 \%$ to the college decision in IAIN Surakarta while the rest were other factors outside of this study.
\end{abstract}

Keywords: quality, location, costs and college decisions

\section{PENDAHULUAN}

Salah satu cara terbaik untuk meningkatkan kualitas hidup manusia adalah melalui investasi di bidang pendidikan. Dengan pendidikan kita memperoleh nilai tambah baik aspek pengetahuan, sikap, maupun ketrampilan. Peningkatan ketiga aspek ini akan membantu kita dengan mudah mampu beradaptasi dalam lingkungan sosial yang dinamis dan berubah cepat.

Kesadaran akan pentingnya pendidikan tersebut di satu sisi telah membuat banyak orang berupaya keras untuk mengakses pendidikan setinggi mungkin, sementara di sisi lain karena banyaknya permintaan maka sebagai konsekwensi logisnya adalah munculnya perguruan tinggi baru yang menawarkan beragam layanan program studi pendidikan, termasuk prodi keagamaan. Hal ini membuat persaingan antar perguruan tinggi menjadi sesuatu yang tidak dapat dihindari lagi. Dan sebagai akibat dari adanya persaingan ini, tidak sedikit lembaga pendidikan tinggi yang kemudian jatuh terperangkap dalam persoalan eksistensial antara bertahan hidup atau berhenti operasional karena minimalnya peserta didik yang bisa dijaring.

Berdasarkan kondisi faktual di atas maka menarik untuk mengetahui tentang faktorfaktor apa yang kemungkinan besar ikut mempengaruhi peserta didik didalam mengambil keputusan untuk memilih kuliah di suatu perguruan tinggi, yang dalam hal ini IAIN Surakarta. Itulah kenapa dalam studi ini peneliti kemudian menjadi tertarik mengambil judul "Pengaruh Kualitas, Lokasi dan Biaya terhadap Keputusan Kuliah di IAIN Surakarta".

Adapun masalah penelitian atau pertanyaan penelitian yang coba dicari jawabannya disini dapat dirumuskan antara lain sbb:

1. Apakah Kualitas Perguruan Tinggi, Lokasi, dan Biaya secara bersama-sama punya pengaruh signifikan terhadap Keputusan Kuliah di IAIN Surakarta? 2. Apakah Kualitas Perguruan Tinggi secara parsial punya pengaruh signifikan terhadap Keputusan Kuliah di IAIN Surakarta? 3. Apakah Lokasi secara parsial punya pengaruh signifikan terhadap 
Keputusan Kuliah di IAIN Surakarta? dan 4. Apakah Biaya secara parsial punya pengaruh yang signifikan terhadap Keputusan Kuliah di IAIN Surakarta?

Sementara itu tujuan dari penelitian ini secara lengkap dapat dipaparkan sebagai berikut: 1. Untuk mengetahui signifikansi pengaruh Kualitas Perguruan Tinggi, Lokasi, dan Biaya secara bersama-sama pada Keputusan Kuliah di IAIN Surakarta. 2. Untuk mengetahui signifikansi pengaruh Kualitas perguruan Tingggi secara parsial terhadap Keputusan Kuliah di IAIN Surakarta. 3. Untuk mengetahui tentang signifikansi pengaruh Lokasi secara parsial terhadap Keputusan Kuliah di IAIN Surakarta. 4. Untuk mengetahui tentang signifikansi pengaruh Biaya secara parsial terhadap Keputusan Kuliah di IAIN Surakarta.

\section{LANDASAN TEORI}

\section{A. Keputusan Pembelian}

Walker (1997: 123) memberi batasan yang utuh mengenai Keputusan Pembelian. Dikatakan bahwa Keputusan Pembelian merupakan suatu proses untuk membeli sebuah produk guna memenuhi kebutuhan.

Sebagai sebuah proses, Keputusan Pembelian tentu bukan kegiatan yang sekali jadi. Dalam memutuskan untuk membeli suatu produk barang atau jasa, terdapat beberapa tahapan yang harus dilalui oleh konsumen. Secara garis besar tahapan itu dimulai dari adanya kesadaran akan kebutuhan, pencarian informasi, penilaian alternatif, dan berakhir pada keputusan pembelian.

Keseriusan konsumen dalam mengikuti tahapan pengambilan keputusan itu akan menentukan kualitas keputusan yang dibuat. Dalam artian ketepatan produk yang dibeli dan keyakinan akan produk yang dipilih tergantung pada proses keputusan pembelian.

Maka bisa disebutkan disini bahwa indikator dari Keputusan Pembelian itu antara lain terdiri: a. Ketepatan produk jasa yang dipilih, b. Kesesuaian produk jasa yang dipilih dan c. Keyakinan akan produk jasa yang dipilih

\section{B. Kualitas}

Kualitas adalah keseluruhan sifat suatu produk atau pelayanan yang memiliki pengaruh pada kemampuan untuk memuaskan kebutuhan baik terlihat dan tidak terlihat (Kotler, 2005:57). Produk atau jasa dikatakan punya kualitas jika apa yang ditawarkan tersebut sesuai atau melampaui ekspektasi konsumen.

Dalam konteks pendidikan, khususnya lagi perguruan tinggi, kualitas ditandai antara lain: 1. Akreditasi kampus dan akreditasi prodi, 2. Jumlah dan kualifikasi staf pengajar 3. Jumlah tenaga administrasi yang cukup dan berkualitas 4. Fasilitas (Gedung kuliah, lab, perpustakaan, Wifi).

\section{Lokasi}

Lokasi berarti tempat secara fisik (Sriyadi, 1991: 60). Terkait dengan kegiatan usaha, lokasi merupakan tempat perusahaan beroperasi atau tempat perusahaan melakukan kegiatan untuk menghasilkan barang dan jasa.

Lokasi merupakan salah satu penentu yang bisa mempengaruhi keinginan konsumen untuk datang. Beberapa indikator lokasi yang menarik konsumen yakni ditandai: a. Akses, dalam arti mudah dijangkau oleh sarana transportasi umum, b. Dekat dengan kediaman, c. Lingkungan yang aman, d. Lalu lintas yang lancer, dan e. Tempat parkir yang luas dan aman. 


\section{Biaya}

Biaya dapat dipandang sebagai suatu nilai tukar yang dikeluarkan atau suatu pengorbanan sumber daya yang dilakukan untuk mendapatkan manfaat di masa datang. Menurut Tjiptono (2002:178), biaya adalah dana yang dibutuhkan untuk mendapatkan suatu kebutuhan tertentu.

Bagi mahasiswa, umumnya biaya menjadi salah satu pertimbangan dalam mengambil keputusan untuk memiih perguruan tinggi. Lebih tepatnya Indikator biaya itu dilihat dari sudut pelanggan antara lain terdiri: a. Keterjangkauan biaya kuliah, b. Tersedianya beasiswa, c. Kesesuaian biaya kuliah dengan kualitas perguruan tinggi dan d. Kemampuan ekonomi keluarga.

\section{E. Kerangka Pemikiran}

Kerangka pemikiran yang merupakan konstruksi hubungan antar variable dari penelitian ini secara skematik dapat peneliti gambarkan sebagai berikut:

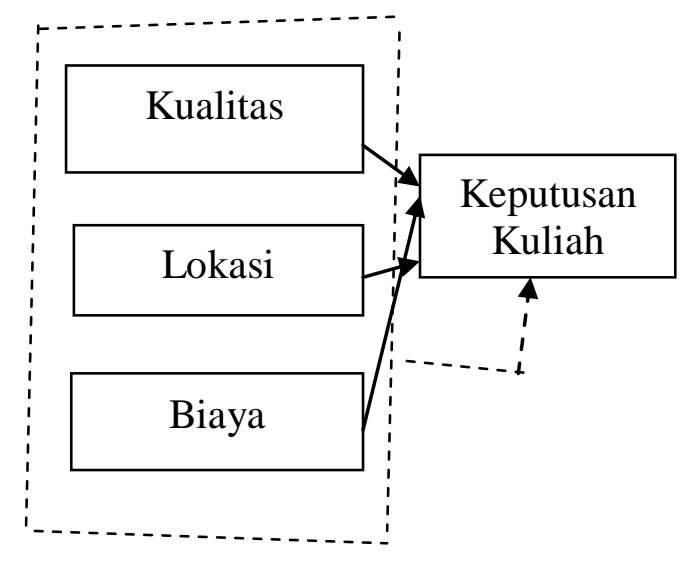

Keterangan :

$\longrightarrow=$ Secara parsial

$\ldots$

\section{METODE ANALISIS}

\section{a. Sumber Data dan Responden}

Populasi dalam penelitian ini meliputi mahasiswa semester 2 (dua) program S1 angkatan tahun 2018/2019 IAIN Surakarta. Keseluruhan jumlah populasi mencapai 3461 mahasiswa.

Sementara itu dalam hal pengambilan sample memakai teknik Random Sampling, yaitu pengambilan sampel secara acak sederhana. Dengan memakai perhitungan rumus Slovin jumlah sample diperoleh sebanyak 100 responden.

Sedangkan instrument yang digunakan penelitian ini adalah berbentuk kuisener. Pertanyaan dalam kuisener bersifat tertutup, yaitu pertanyaan dengan pilihan jawaban yang sudah disediakan. 


\section{b. Metode Analisis Data}

Uji validitas yang dipakai adalah metode Pearson Product Moment (Ridwan, 2004). Sedang uji reliabilitasnya menggunakan metode Alpha.

Sementara uji Asumsi klasik meliputi tiga: 1. Uji normalitas (Kolmogorov-Smirnov). 2. Uji heteroskedastisitas dengan scatter plots dan uji glejser. 3. Uji multikolinearitas.

Dan uji hipotesa yang digunakan dalam penelitian ini masing-masing analisa regresi berganda, uji F dan Uji t, serta Koefisien Determinasi $\left(\mathrm{R}^{2}\right)$.

\section{HASIL DAN PEMBAHASAN}

\section{Hasil Analisa Data}

Hasil uji validitas yang dilakukan menunjukkan bahwa semua pernyataan adalah valid. Hal ini terbukti dengan nilai $r_{\text {hitung }}$ lebih besar dari 0,444 .

Selain itu semua butir dari pertanyaan dalam variabel penelitian bisa dikatakan reliabel (terpercaya). Hal itu ditandai oleh uji Reliabilitas nilai koefisien Cronbach Alpha pada seluruh variable yang nilainya lebih besar dari 0,6.

Adapun uji asumsi klasik dapat diperoleh hasil berikut ini: a. Hasil uji normalitas telah menunjukkan bahwa data pada semua variable dalam keadaan terdistribusi normal. Hal ini tampak ditunjukkan oleh masing-masing hasil perhitungan nilai signifikansi $(\mathrm{p}=0,321)$ dari variabel keputusan kuliah, nilai signifikansi $(\mathrm{p}=0,185)$ variabel kualitas, dan nilai signifikansi $(\mathrm{p}=0,539)$ variabel lokasi, serta nilai signifikansi $(\mathrm{p}=0,340)$ dari variabel biaya; yang terbukti keseluruhannya lebih besar dari nilai kritisnya yakni 0,05. b. Hasil uji heteroskedastisitas dengan scatterplots diketahui titik-titik datanya menyebar dan tidak berpola, sedang dari hasil uji glejser nilai Signifikansi pada seluruh variabel lebih besar 0,05. Karena itu dapat disimpulkan disini bahwa tidak terjadi heteroskedastisitas. c. Hasil uji multikolinearitas menunjukkan bahwa nilai tolerance > 0,01 dan nilai VIF < 10, sehingga bisa disimpulkan bahwa tidak terjadi multikolinearitas.

Sementara itu dari uji hipotesis dapat dipaparkan sbb: a. Hasil analisis regresi linear berganda diperoleh persamaan:

$Y=5,327+0,411 X_{1}+0,344 X_{2}+0,247 X_{3}$

Persamaan regresi tersebut dapat dibaca: nilai konstanta (a) $=5,327$ berarti jika semua variable pengaruh tetap maka keputusan kuliah akan meningkat sebesar 5,327 dan positip; nilai kualitas meningkat maka keputusan kuliah akan meningkat sebesar 0,411 dan positif; nilai lokasi meningkat maka keputusan kuliah akan meningkat sebesar 0,344 dan positif; dan nilai biaya meningkat maka keputusan kuliah akan meningkat sebesar 0,247 dan positif. b. Uji F sebesar 28,984 dan ( $\mathrm{p}<0,05)$, artinya kualitas, lokasi dan biaya berpengaruh secara simultan dan signifikan terhadap keputusan kuliah pada IAIN

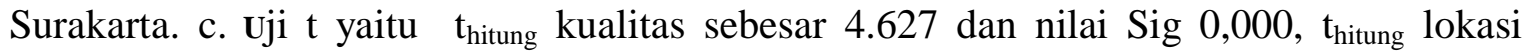

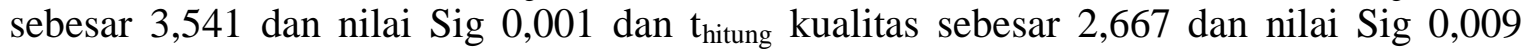
berarti kualitas, lokasi dan biaya berpengaruh secara parsial dan signifikan terhadap keputusan kuliah. d. Koefisien determinasi menunjukkan Nilai Adjusted $R$ Square $\left(\mathrm{R}^{2}\right)$ sebesar $0,459=45,9 \%$ yang berarti bahwa variabel kualitas, lokasi dan biaya memiliki pengaruh terhadap variabel keputusan kuliah di IAIN Surakarta sebesar 45,9 \% dan sisanya sebesar 54,1\% adalah variabel lain diluar dari variabel dalam penelitian ini, seperti promosi, motivasi, orang, proses, budaya, sosial, psikologis, kelompok acuan dan lain-lain. 


\section{Pembahasan}

1) Uji F menunjukkan variabel kualitas, lokasi dan biaya berpengaruh secara bersama-sama dan signifikan terhadap keputusan kuliah di IAIN Surakarta. Nilai $\mathrm{F}_{\text {hitung }}$ sebesar 28,984.

2) Nilai $t_{\text {hitung }}$ variabel kualitas yang paling tinggi yaitu sebesar 4,627. Semakin baik kualitas maka keputusan kuliah di IAIN Surakarta semakin tinggi.

3) Nilai $t_{\text {hitung }}$ variabel lokasi sebesar 3,541. Semakin mudah lokasi maka keputusan kuliah di IAIN Surakarta semakin tinggi.

4) Nilai $t_{\text {hitung }}$ variabel biaya sebesar 2,667. Semakin terjangkau biaya maka keputusan kuliah di IAIN Surakarta semakin tinggi.

\section{KESIMPULAN DAN SARAN}

A. Kesimpulan

1) Kualitas, lokasi dan biaya berpengaruh secara simultan dan signifikan terhadap variabel keputusan kuliah.

2) Kualitas, lokasi, dan biaya berpengaruh positif dan signifikan terhadap keputusan kuliah.

3) Kualitas, lokasi dan biaya memberikan kontribusi sebesar $45,9 \%$ terhadap keputusan kuliah di IAIN Surakarta.

\section{B. Saran}

1) Perlu meningkatkan kualitas IAIN Surakarta dengan cara meningkatkan kualitas dosen dan karyawan, reward untuk dosen berprestasi, menambah anggaran penelitian dll.

2) Kemudahan akses lokasi IAIN Surakarta ditingkatkan dengan cara menambah lokasi baru yang lebih strategis.

3) Menetapkan biaya kuliah yang terjangkau, kerjasama dengan lembaga yang menyediakan beasiswa. 


\section{DAFTAR PUSTAKA}

Boyd L. Walker, (1997), Manajemen Pemasaran, Jilid I, Ahli Bahasa Oleh Imam Nurmawan, Jakarta: Erlangga.

Kotler, Philip dan Kevin Lane Keller. (2009). Manajemen Pemasaran. Edisi ketigabelas (Terjemah: Benyamin Molan). Jakarta: PT.Indeks.

Kotler, Philip. (2005). Manajemen Pemasaran. Edisi kesebelas Jilid II (Alih Bahasa : Benyamin Molan). Jakarta: PT. Indeks.

Sriyadi. (1991). Bisnis, Pengantar Ilmu Ekonomi Perusahaan Modern. Semarang: IKIP Semarang Press.

Riduwan. (2004). Metode dan Teknik Menyusun Tesis. Bandung: Alfabeta.

Tjiptono, F. (2002). Pemasaran Jasa. Malang: Bayumedia Publishing. 